\title{
A ORGANIZAÇÃO DA JUSTIÇA MILITAR NO BRASIL: IMPÉRIO E REPÚBLICA
}

\author{
The organization of Military Justice in \\ Brazil: Empire and Republic
}

\author{
ADRIANA BARRETO SOUZA \\ E ANGELA MOREIRA DOMINGUES DA SILVA
}

http://dx.doi.org/10.1590/S2178-14942016000200003

Adriana Barreto Souza é doutora em História (UFRJ), professora associada da Universidade Federal Rural do Rio de Janeiro (UFRRJ), Jovem Cientista do Nosso Estado da Fundação Carlos Chagas Filho de Amparo à Pesquisa do Estado do Rio de Janeiro (Faperi) desde 2013, e Bolsista de Produtividade do Conselho Nacional de Desenvolvimento Científico e Tecnológico (CNPq) (adrianaabarreto@gmail.com).

Angela Moreira Domingues da Silva é doutora em História (CPDOC/FGV), professora adjunta do Programa de Pós-Graduação em História, Política e Bens Culturais (PPHPBC) e da Escola de Ciências Sociais da Fundação Getulio Vargas, e Jovem Cientista do Nosso Estado da Fundação Carlos Chagas Filho de Amparo à Pesquisa do Estado do Rio de Janeiro (Faperj) desde 2015 (angelamoreirads@gmail.com).

Artigo recebido em 30 de abril e aprovado para publicação em 15 de junho de 2016.

As pesquisas que fundamentam esse artigo são financiadas pelo CNPq e pela FAPERJ. 


\title{
RESUMO
}

A proposta do artigo é apresentar a estrutura e o funcionamento da justiça militar ao longo da história do Brasil, abarcando os períodos imperial e republicano. Para tanto, optou-se por mapear e analisar a legislação que delineia os contornos dessa justiça, considerando sua composição, suas atribuições e o alcance de seu trabalho, julgando militares e civis. A criação e a permanência de um foro militar pouco definido estão intimamente relacionadas ao debate sobre a profissionalização da carreira e o gradativo envolvimento dos militares com questões políticas, até se firmarem como atores políticos relevantes a partir da instauração do regime republicano.

PalaVras-ChaVE: justiça militar; foro militar; crime militar; crime político.

\begin{abstract}
The purpose of the article is to present the structure and functioning of the military justice throughout Brazil's history, including the imperial and republican periods. To do so, we decided to map and analyze the legislation responsible for outlining the contours of this justice, considering its composition, its attributions and the scope of its work, judging military and civilian. The creation and persistence of an undefined military court are closely related with the discussions about military professionalization and the gradual involvement of the military in political issues, until they established themselves as relevant political actors with the instauration of the republican regime.
\end{abstract}

KeYwords: Military Justice; military court; military crime; political crime.

\section{RÉSUMÉ}

L'article veut présenter la structure et le fonctionnement de la Justice Militaire au long de l'histoire du Brésil, en englobant les périodes impériale et républicaine. Dans ce sens, nous irons cartographier et analyser la législation qui encadre cette justice, en observant sa composition, ses attributions et ses compétences par rapport aux militaires et aux civils. La création et la persistance d'une jurisdiction militaire peu définie sont intimement liées au débat sur la professionnalisation de la carrière militaire et l'implication croissante des militaires dans des questions politiques, jusqu'à ce qu'ils deviennent des acteurs politiques de premier plan à partir de l'instauration du régime républicain.

Mots-CLÉs: Justice Militaire; tribunal militaire; crime militaire; crime politique. 
m decisão de 2013, o Supremo Tribunal Federal (STF) definiu a competência da justiça militar para julgar civis acusados de crimes militares, como desacato, cometidos em "ocasiões excepcionais" nas quais se incluem as operações de "pacificação" que têm sido efetuadas no Rio de Janeiro com o auxílio do Exército." Esta recente deliberação sobre os contornos e a competência do foro militar reflete a própria história da justiça militar brasileira.

A justiça militar brasileira foi um dos primeiros ramos formais do sistema de justiça a ser criado no país com a vinda da família real portuguesa em 1808. 0 ramo existe até hoje e desde 1934 integra o rol das justiças especiais do Poder Judiciário, junto com a justiça do trabalho e a justiça eleitoral. Sua atribuição e seus contornos jurídicos, no entanto, permanecem fluidos desde a sua criação, estendendo sua função para julgar militares, civis, crimes militares ou políticos. Logo após a proclamação da República, por exemplo, a justiça militar transbordou de suas apreciações voltadas para crimes de natureza estritamente militar, como deserção, para se envolver sucessivamente com questões de natureza política.

Defendemos que a estruturação da justiça militar, associada na Europa do século XIX à profissionalização da carreira militar (Berbouche, 2010; Guinier, 2014), assumiu contornos específicos no Brasil, acompanhando a crescente afirmação dos militares como atores políticos relevantes.

Sua relação com as Forças Armadas e com o Poder Judiciário permite-nos afirmar que ela se mantém na intersecção entre o mundo militar e o mundo jurídico, constituindo-se como uma esfera híbrida de atuação, moldada pelas formalidades jurídicas e perpassada pelo ethos militar. Como toda justiça especial, trata-se de um campo que apresenta particularidades envolvendo sua composição, atribuição e definição do tipo criminal que pode ser julgado por ela.

Poucas são as pesquisas na área da história dedicadas a refletir sobre a justiça militar brasileira. Em geral, a produção acadêmica sobre as funções e a atuação desse ramo do Judiciário é elaborada por profissionais do campo do direito ou por integrantes do próprio foro militar. Não há um estudo sistematizado que acompanhe a história institucional da justiça militar, ${ }^{2}$ e que dê conta de suas particularidades, tanto com relação à sua formalização normativa, quanto com relação à sua atuação pragmática. No caso da história do Brasil Império, podemos dizer que se trata de um terreno inexplorado. No caso do Brasil República, os estudos vinculam-se mais à sua atuação durante períodos autoritários, circunscritos 
ao seu desempenho como foro político (Arquidiocese de São Paulo, 1985; Coitinho, 2012; D'Araujo, 2010; Lemos, 2004 e 2012; Mattos, 2002; Maciel, 2003; Pereira, 2010; Silva, 2007, 2011, 2014).

0 objetivo deste artigo é, portanto, acompanhar o processo de criação e estruturação da justiça militar brasileira, do século XIX ao XXI, apresentando as sucessivas modificações que nela foram implementadas ao longo da história do Brasil independente, e optando por um recorte de longo alcance temporal. Um movimento descontínuo que será analisado a partir de um enfoque legislativo, examinando-se paralelamente os limites do foro militar em cada contexto.

\section{A JUSTIÇA MILITAR NO IMPÉRIO DO BRASIL}

Eu servi no 2- Regimento do Porto (...) ali, em 1764, procedeu-se a Conselho de Guerra, e porque neste quiseram comutar, a seu puro arbítrio, ou em menosprezo da lei, o castigo que correspondia (...) a resolução foi que mandasse imediatamente dar baixa ao auditor, uma grande repreensão aos vogais, e que se procedeu a novo Conselho.

(Ten.-gal. José Narcizo de Magalhães e Menezes)

$\mathrm{D}$ urante o ano de 1803, o comandante das tropas do Rio de Janeiro, José Narcizo de Magalhães e Menezes, enviou vários ofícios ao vice-rei D. Fernando José de Portugal, denunciando a incúria com que se procedia a Conselhos de Guerra na cidade. Queixava-se da falta de zelo na apuração dos fatos, e da não observação dos procedimentos previstos em lei. A serviço no Rio de Janeiro desde 1799, o militar por várias vezes fundamentou suas críticas - como se vê na epígrafe - em experiências anteriores, vividas ainda em Portugal. Defendia que do bom funcionamento dos Conselhos de Guerra dependia a "disciplina da tropa", pilar de sustentação da "profissão militar". 3

Os Conselhos de Guerra evocados pelo general Magalhães e Menezes eram uma instituição relativamente nova em Portugal. Tinham sido criados em fevereiro de 1763, como pequenos tribunais, atrelados aos Regimentos, para funcionar como primeira instância da justiça militar. Assim como a Intendência Geral de Polícia, criada três anos antes, os Conselhos de Guerra eram expressão de uma política reformista que procurava instituir em Portugal práticas administrativas interventivas (Abreu, 2013; Hespanha, 1993; Subtil, 2013). 0 discurso do general é surpreendente. Além de mostrar preocupação em seguir o "registro da lei", o faz de um lugar preciso, e inteiramente novo - 0 da profissão militar, o do especialista da guerra. ${ }^{4}$ 
Esse discurso apostava em uma extensa transformação institucional, capaz de fornecer ao Estado meios para intervir e organizar espaços sociais. No campo militar, a referência europeia, mesmo para a França iluminista, era o Exército prussiano, que abandonava os princípios de voluntarismo e coragem para se organizar a partir da disciplina, o que exigiu uma reestruturação das forças militares europeias (Guinier, 2014: 19).

É nesse contexto que a justiça militar é reformada em Portugal e gradativamente instituída como área específica do domínio jurídico, com lógica e temas próprios, que deveriam pôr em prática procedimentos regulares de disciplinarização da tropa e de resolução de conflitos. Até então, essa justiça funcionava a partir de uma lógica institucional pluralista, de Antigo Regime. Em termos práticos, isso implicava um sistema ordenado em torno de autoridades (não de tribunais), de devassas (não de processos com provas) e de um foro militar pouco definido (Souza, 2014).

Na França, a crítica a esse sistema fomentou um debate público na virada do século XVIII para o XIX. ${ }^{5}$ Em Portugal, o debate é menos explícito. ${ }^{6}$ Porém, se ambos os países olhavam com interesse para a Prússia, havia uma ideia, cara aos franceses, que funcionou como um filtro para o debate em Portugal: a necessidade de se conciliar a disciplina com "o espírito da nação" (Guinier, 2014:20).

Enquanto os franceses não viam meios de submeter "o amor pela pátria de seus soldados" à disciplina prussiana, no Império luso-brasileiro o debate ganhava contornos distintos, definidos pelo predomínio de uma população mestiça. No Rio de Janeiro, o general Magalhães e Menezes só se mobilizou para o tema quando foi surpreendido, em 1805, por uma sublevação no Regimento de Pardos da cidade. ${ }^{7}$ Três anos depois, em 1808, com a chegada da corte imperial, esse debate sobre a formalização da justiça militar e suas instituiç̧̃̃es se enraizou no Brasil.

Em termos institucionais, de 1822 a 1827, a justiça militar do nascente Império incorporou todas as instituições portuguesas criadas nesse debate. Ficou organizada em torno de três instituições ordinárias - os Conselhos de Disciplina, os Conselhos de Guerra e o Conselho Supremo Militar e de Justiça (CSMJ) - e uma instituição de exceção - a Comissão Militar. Em 1827, foram criadas em algumas províncias do norte as Juntas de Justiça militar, única alteração realizada por D. Pedro I. Porém a instituição não era nova. É possível localizar referências a essas Juntas em 1758, ou seja, nessa mesma herança setecentista portuguesa.

Nesse período - com funcionamento durante todo o Império - a justiça militar contava com duas instâncias principais de julgamento dos crimes militares. A primeira eram os Conselhos de Guerra. Criados em 1763 (para a Marinha apenas 20 anos depois, por decreto de 15 de novembro de 1783), as bases legislativas desses conselhos permaneceram quase 
inalteradas até a República. Não eram instituições permanentes. Atendiam a demandas específicas de cada Regimento e organizavam-se em torno destes. Cada Conselho de Guerra devia ser integrado por um presidente, um auditor e cinco oficiais militares, denominados vogais. Porém a instituição do cargo de auditor em cada Regimento militar, o "auditor regimental", grande novidade da época, não vingou. Por alvará de 26 de fevereiro de 1789, o cargo de auditor regimental foi extinto e suas funções passaram a ser exercidas pelos juízes do crime ou juízes de fora da cidade onde o Regimento estivesse aquartelado. As patentes militares do presidente e dos vogais do Conselho de Guerra nunca poderiam ser inferiores à do réu, respeitando-se o princípio hierárquico militar. Também deveria ser observada a qualidade social do réu. Sendo este cavaleiro de alguma das ordens militares, os vogais e o presidente do Conselho deveriam ter a mesma condição social, pertencendo também às ditas ordens. ${ }^{8}$

Essa interferência de princípios hierárquicos sociais, de base aristocrática, na composição dos Conselhos de Guerra já mostra o quanto o discurso do "especialista militar", em circulação desde fins do século XVIII, permaneceu limitado no Brasil. Mas, por outro lado, há alguns avanços do ponto de vista formal. Vários procedimentos foram legalmente definidos. A informalidade dos interrogatórios, constituídos apenas de perguntas feitas aos réus, deduzindo-se daí a sentença final, foi substituída pela constituição da figura jurídica do corpo de delito (Sampaio, 1824: 50). Este, à época, tinha por base um formulário em que se registrava o nome do réu, local, data e hora do crime, uma descrição do mesmo, identificando-se, por fim, a lei militar infringida. De posse desta peça, respaldada por comprovantes, o presidente convocava o Conselho de Guerra. Ao auditor caberia formar, então, um relatório - o auto de corpo de delito. 0 interrogatório, antes livre, ficando as perguntas ao arbítrio dos juízes, a partir de agora só poderia ser deduzido desse documento. Também eram os autos que fundamentavam a escolha das testemunhas, de defesa e de acusação - outra novidade da época (Idem: 10-21).

A segunda instância da justiça militar era constituída pelo Conselho Supremo Militar e de Justiça. Este órgão foi criado por alvará de 1ํ de abril de 1808. Todavia, o próprio alvará estabelecia uma continuidade entre o novo órgão e seu congênere português, o Conselho de Guerra de Lisboa, afirmando que o novo órgão era regulado pelo Regimento de 22 de dezembro de 1643, e pelas mais ordens régias que regiam o Conselho de Guerra de Lisboa. ${ }^{9}$ Essas outras ordens régias se inscreviam justamente no contexto das reformas do final do século XVIII, quando D. Maria I interveio nessa estrutura. As antigas sessões destinadas aos assuntos da justiça militar foram substituídas por um tribunal militar, batizado de Conselho de Justiça, com funcionamento no próprio Conselho de Guerra de Lisboa (Souza, 2014: 398).

A experiência formou a segunda instância da justiça militar criada em 1808, que apesar das duras críticas que recebeu - funcionou sem alterações expressivas até a República 
(Souza, 2012). 0 CSMJ nasceu no Brasil com duas seções bem demarcadas: um Conselho de Justiça, que mantinha a função de tribunal militar, e um Conselho Militar, destinado às questões burocráticas da caserna. Os dois Conselhos, reunidos, constituíam um único órgão - 0 Conselho Supremo Militar e de Justiça. Outra marca dessas experiências de finais do século XVIII foi a decisão de centralizar neste Conselho a administração e a justiça militar do Exército e da Marinha. Em Portugal, desde 1795, havia um órgão específico para a Marinha, o Conselho do Almirantado. No Brasil, só em 1856 foi criado órgão semelhante, o Conselho Naval, ainda assim sem funções jurídicas. ${ }^{10}$

0 número de conselheiros que compunha o Conselho Militar não era especificado no alvará, variando de acordo com os interesses da Coroa. Define-se apenas que todos os oficiais-generais do Exército e da Armada que tivessem o título de conselheiro de Guerra (ou do Almirantado em Portugal) integrariam o novo Conselho. Para além desses, haveria ainda - tal como em seu congênere português - oficiais de uma ou outra força nomeados como vogais. Já o Conselho de Justiça seria composto por três juízes togados, sendo um deles ministro relator e os dois outros adjuntos, além dos conselheiros de Guerra e vogais que quisessem participar das sessões. A nomeação para esses cargos era realizada pela Coroa, e os cargos eram vitalícios.

Se toda essa estrutura aponta para a formalização do campo da justiça militar no Brasil, por outro lado seus limites são nítidos. A condição para o pleno funcionamento dessas instituições era a definição precisa do foro militar. Ou seja, quem estaria submetido à justiça militar e qual o alcance jurisdicional dessas novas autoridades. 0 tema foi oficialmente pautado pela primeira vez em 1802, quando da criação pelo príncipe regente D. João, ainda em Portugal, de uma Junta destinada à elaboração de um código penal militar. ${ }^{11}$

De início, as sessões da Junta mobilizaram seus membros, que se dedicaram à coleta de códigos de outros países e à sistematização da legislação militar portuguesa, muito dispersa. Todavia, logo em seguida, as reuniões não alcançavam mais o quórum mínimo. 0 tema que esvaziava os debates era justamente o do foro militar. De modo geral, é possível identificar a polarização do debate em torno de duas posições. A primeira defendia uma concepção antiga de foro, definida como "objeto honorífico". Por esta perspectiva, o foro militar era uma lei particular, que assegurava aos oficiais direito de administração da justiça e, até mesmo, liberdade de interpretação das leis. Isso não só lhes dava acesso, caso cometessem um crime (fosse este militar ou não), a uma justiça especial, como lhes garantia amplo poder jurisdicional sobre as regiões onde as tropas se achavam estacionadas. Quem partilhava dessa perspectiva defendia que a Junta deveria se limitar a reduzir, compilar e pôr em melhor ordem a legislação militar existente. $^{12}$ 
A segunda posição investia em uma nova concepção de foro militar. Por ela, o foro não era um privilégio, algo individual, destinado a pessoas tidas como de qualidade social superior. Invertendo a lógica antiga, tratava-se antes de um ônus: "rigor imposto aos soldados" para "manter pelo terror a boa ordem". o que se pautava era a necessidade de disciplinar tropa e oficialidade, a fim de aumentar a eficácia do Exército.

A opção tomada em 1806, de dissolver a Junta sem que um código penal militar tivesse sido aprovado, limitava por si o funcionamento da justiça militar. Sem um código penal militar, não se legislava sobre o foro militar, que, permanecendo aberto, podia levar - sem qualquer critério - civis a tribunais militares, e tirar oficiais do alcance da justiça comum. Também não se legislava sobre crimes e penalidades, deixando-se de regular as relações hierárquicas internas, e sem esta regulamentação, de se estabelecer a disciplina como valor constitutivo da instituição.

Diante das polêmicas, a Junta do Código Penal Militar conseguiu aprovar apenas uma Ordenança para Desertores em Tempo de Paz, encaminhando por meio dela um problema crônico nas tropas portuguesas - o da deserção. Foi essa Ordenança, de 9 de abril de 1805, que criou os Conselhos de Disciplina (Sampaio, 1824: 71).

Após caracterizar o crime de deserção como falta por oito dias consecutivos ao serviço militar, ou excesso de licença, que ultrapassasse o limite de 30 dias, a referida Ordenança definia que as faltas entre três e oito dias e que não configurassem deserção, fossem julgadas por Conselhos de Disciplina. Cada Conselho era composto por três oficiais superiores e dois capitães, que não podiam pertencer à companhia do réu. A defesa deste era ouvida pelo Conselho, que Ihe impunha a pena que julgasse apropriada, sendo produzido um assento (registro), que seguia lavrado pelo vogal mais moderno (com menos tempo de serviço) e assinado por todos. Já nos casos de crime de deserção, o réu seria levado a Conselho de Guerra, servindo o "assento" como corpo de delito. Há ainda dois pontos importantes. 0 primeiro é sobre 0 alcance da Ordenança, que se limitava aos soldados e oficiais inferiores. Isso significa que as faltas ao serviço do restante da oficialidade (de alferes a marechal do Exército) permaneciam sem regulamentação. Outro ponto é que a punição das faltas de até três dias de soldados e inferiores ficava oficialmente "ao arbítrio dos coronéis" dos Regimentos (Idem: 72).

0 domínio do arbitrário, simbolizado pela aplicação de punições instantâneas e brutais, fora de um enquadramento legal, persistia. E, sem a regulamentação do foro, esse aparato militar ainda poderia ser acionado para julgar réus civis. Talvez, por esta razão, a Comissão Militar, tribunal de exceção a que D. João VI e D. Pedro I recorreram por diversas vezes, tenha se tornado obsoleta após 1831. Para além das críticas liberais, particularmente intensas a partir de 1824, após a polêmica repressão à Confederação do Equador (Souza, 2008: 138-160), 
sem uma definição precisa do foro militar, quando necessário, os Conselhos de Guerra poderiam ser usados na repressão a movimentos populares, punindo também civis.

Como tribunal de exceção, a Comissão Militar era um dispositivo acionado para dar ares de julgamento à ação do Estado na repressão a movimentos contestatórios. Esses tribunais eram presididos pelo comandante das forças de repressão em operação no local e integrados apenas por militares, sem contar com a presença de sequer um juiz togado. 0 réu, sem direito a advogado, e sem poder fazer ele próprio sua defesa, era processado de forma sumária e verbal.

A partir de 1831, com o avanço liberal, esse dispositivo - ao que parece - caiu em desuso, sendo acionado novamente após a proclamação da República. ${ }^{13}$ Na verdade, após a abdicação de D. Pedro I, o governo regencial avançou em várias reformas que tentavam desmontar instituições do Primeiro Reinado, tidas como arcaicas. No campo da justiça militar, essas reformas colocavam no centro do debate o CSMJ. Em seu lugar, os liberais propunham a adoção de Juntas de Justiça Militar por todo o Império. Como vimos, essas Juntas foram criadas no Brasil em 1827, já num contexto de crítica aos arbítrios de D. Pedro I. Desde então, constituíam de forma permanente a segunda instância da justiça militar no Pará, Maranhão, Bahia e Pernambuco, sendo justificadas pela distância e dificuldades de comunicação dessas províncias com o CSMJ, no Rio de Janeiro. Em 1831, a proposta era outra. Defendia-se a extinção do CSMJ e, paralelamente, pautava-se pela primeira vez a elaboração de um código penal militar brasileiro.

Nem uma nem outra proposta foi adiante. Diante do avanço dos movimentos contestatórios pelo Brasil, o ímpeto liberal, que impulsionou a quase imediata reforma do aparelho militar e jurídico do Estado, não chegou a transformar a justiça militar. Ao invés de discutir as instituições existentes, criou uma nova. Por decreto de 26 de maio de 1835, a Regência finalmente regulou as penas para o crime de deserção dos oficiais do Exército e da Armada, criando um órgão específico, o Conselho de Investigação. À diferença dos demais, sua composição não era definida na lei. Declarava-se apenas que seria integrado por três oficiais e à vista do depoimento de testemunhas. Em contrapartida, a lei definia as punições, que variavam entre prisão - precisando-se o tempo de detenção para cada caso - até pena de morte, passando por expulsão. Outra diferença é que, ao contrário do que acontecia com soldados e oficiais inferiores, pela letra da lei, a deserção da oficialidade não formava processos em Conselho de Guerra, esgotando-se no âmbito dos Conselhos de Investigação.

Essa é uma estratégia política que merece destaque. Seis anos depois, em 1ำ de dezembro de 1841, mais uma nova instituição vinculada à justiça militar foi criada: os Conselhos de Inquirição. Assim como os de Investigação, eles aparecem no meio do texto 
de leis que regulavam questões específicas e que tentavam criar mecanismos de controle sobre a oficialidade. Se a lei de 1835 tinha como objetivo regular as penas para o crime de deserção, a de 1841 organizava o quadro dos oficiais do Exército e da Marinha. Todavia, a lei fazia menção a um novo Conselho, inexistente até então, e que naquele momento foi instituído. Por meio dele, "o governo pode reformar qualquer oficial por motivo de mau comportamento" ${ }^{14} 0$ mais delicado é que, só tendo sido regulamentando 14 anos depois, em 1855, esse parágrafo forneceu ao governo uma excelente arma política. 0 Conselho de Inquirição podia ser acionado pelo Ministério da Guerra como melhor Ihe conviesse, sem que procedimentos precisassem ser observados. ${ }^{15}$ Estratégia útil, considerando que o Império se achava convulsionado de norte a sul, contando alguns movimentos com a adesão de militares.

0 contexto aqui também já era outro. 0 Partido Conservador vinha exercendo a direção do Império desde 1837, e abria espaço para uma ampla reforma militar, que recuperasse o Exército e a Marinha, desmobilizados pelos liberais de 1831 (Souza, 1999). A ampliação das forças militares exigia maior controle sobre a oficialidade. Nosso interesse, porém, é identificar as estratégias e mecanismos de controle então adotados. Por um lado, aumentava-se o número de instituições com jurisdições pouco definidas e que se sobrepunham. Por outro, não se votavam os vários projetos de código penal militar elaborados até a década de 1870 (Souza, 2012). Essas estratégias devem ser lidas como opção política. Sem uma definição precisa do foro militar ou do que era crime militar, instituições como o Conselho de Guerra, ou o CSMJ, podiam ser acionadas com liberdade, inclusive para julgar civis.

\section{A JUSTIÇA MILITAR NA REPÚBLICA BRASILEIRA}

A proclamação da República em 1889 trouxe os militares para o centro do debate po-
lítico. Acompanhando o novo regime, foram promovidas reformas institucionais que de certa forma espelhavam as nascentes modificações políticas. Com a justiça militar não foi diferente, ainda que as dificuldades para sistematizar seus contornos e esfera de atuação tenham perpassado toda a história republicana. ${ }^{16}$ Com a sua existência prevista em todas as Constituições, as atribuições do foro militar foram demarcadas com o seu direcionamento para o julgamento do crime militar, e não do profissional militar, deixando margem para a possibilidade de julgamento de civis.

Nos primeiros anos da República, a justiça militar permanecia com a mesma estrutura herdada do Império, mantendo inclusive a prática imperial de recorrência às comissões militares ad hoc, com o objetivo de lidar judicialmente com situações de oposição política. 
No mês seguinte à Proclamação da República, o presidente marechal Deodoro da Fonseca editou o Decreto no 85-A, conhecido como "decreto-rolha", que dispunha sobre a criação de uma "comissão militar para julgamento dos crimes de conspiração contra a República e seu governo, aplicando-lhes as penas militares de sedição". "17 A finalidade do decreto era a contenção de possíveis movimentos simpatizantes da deposta Monarquia, fossem eles colocados em prática por civis ou por militares. Essa estratégia de repressão a manifestações de natureza política tinha um duplo sentido: o acionamento de uma prática que remetia ao arcabouço da estrutura militar, ou seja, uma comissão militar que deveria ser nomeada pelo ministro da Guerra, e a criação de um mecanismo excepcional para a organização da justiça militar, para julgar "militarmente" aqueles contrários à República, única alternativa para o país, em detrimento da "anarquia" e da "desordem". ${ }^{18}$

A essa altura, o tema da modernização da codificação penal militar permanecia tão atual quanto durante o período imperial. Além dos debates sobre a configuração do foro militar, outros assuntos que incidiam diretamente no trabalho da justiça militar e no funcionamento do cotidiano militar eram alvo de críticas por parte dos que desejavam modificações na legislação penal da época, considerada ultrapassada e anacrônica. ${ }^{19}$

Em decorrência desse movimento de reivindicações, o ministro da Guerra baixou um aviso em janeiro de 1890 que tratava da organização de uma comissão com vistas à elaboração dos códigos penal e de processo penal militar. Tais dispositivos deveriam "preencher a lacuna que considerava fruto da 'indiferença com que o regime decaído olhava as mais vitais necessidades reclamadas por uma sábia organização militar'" (Sampaio, 1976: 67). Em novembro do mesmo ano, foi editado o Decreto nํ 949, estabelecendo finalmente um Código Penal, destinado somente à Armada.

Inspirado por "costumes modernos", o novo código visava a propagação do "espírito de ordem, disciplina e fidelidade ao dever" ${ }^{20}$ Em seus artigos o documento instituía a impossibilidade de retroatividade da lei penal e, entre outras disposições, previa aplicações de penas a militares, assemelhados ao serviço da Marinha de Guerra e civis que praticassem atos que denotassem levante contra o governo, como espionagem. ${ }^{21}$ As penas previstas no código incluíam morte por fuzilamento, prisão com trabalho, prisão simples, degradação militar, destituição, demissão, privação de comando e reforma. ${ }^{22}$

A promulgação da primeira Constituição republicana previa a existência de um foro especial para julgar os delitos militares, cometidos por "militares de terra e mar". Assegurava a existência de conselhos voltados para a formação de culpa e julgamento dos crimes e, também, de um Supremo Tribunal Militar (STM). Dois anos após a promulgação da Carta, foi publicado o Decreto Legislativo no 149, responsável por organizar e regulamentar os trabalhos do 
Supremo. Segundo o documento, o tribunal teria sua sede na capital federal e seria composto de 15 membros vitalícios, nomeados pelo presidente da República. Sua composição seria de oito ministros do Exército, quatro da Armada e três juízes togados.

Eram funções do STM: estabelecer a forma processual militar; julgar em segunda e última instância os crimes militares; responder a consultas da Presidência da República sobre economia, disciplina, direitos e deveres das forças de terra e mar; decidir pela expedição de patentes militares, entre outras. Nesse momento, de recente transição de um regime para outro, o novo Tribunal continuou exercendo funções de natureza administrativa que competiam ao originário CSMJ.

Na segunda década do século XX, houve uma importante reorganização desse foro, cujas bases persistem até hoje. Em 1920, dois decretos foram responsáveis pelo estabelecimento do Código de Organização Judiciária e Processo Militar, encarregado de dar racionalidade à estruturação da primeira instância da justiça militar, de acordo com uma divisão administrativa do território brasileiro em 12 Circunscrições. ${ }^{23} \mathrm{~A}$ partir de então, a configuração da primeira instância do foro militar também foi modificada, dando lugar às auditorias militares, tendo o STM como instância de recurso. Para a realização do trabalho judicial, as auditorias militares passaram a contar com o funcionamento de Conselhos de Justiça Militar, que seriam compostos por um auditor civil e quatro juízes militares, sendo estes nomeados por meio de sorteio entre integrantes do oficialato. ${ }^{24}$

Essa racionalização da estrutura e do funcionamento da justiça militar repercutiu na composição do STM, que foi diminuída para nove ministros vitalícios, nomeados pelo presidente da República, sendo quatro civis, três do Exército e dois da Armada. A partir desse momento, a predominância de ministros civis aumentou em relação à quantidade de ministros do Exército, que se manteve proeminente em relação à Marinha.

A justiça militar não passaria ilesa à turbulência política da década de 1930. Em novembro de 1931, o Governo Provisório baixou decreto determinando o processo e julgamento pela justiça militar de militares, assemelhados ou civis que tomassem parte "por qualquer forma nos atentados contra a ordem pública ou contra os governos da União e dos estados. " 25 No preâmbulo do documento, o Governo Provisório destacava como até então estava sendo "magnânimo na repressão dos crimes praticados contra a ordem pública", que continuava sendo subvertida por civis e militares, e dizia que o governo deveria "reprimir severamente a reprodução desses fatos contrários à organização social e política do país, exigindo, no interesse, fórmula processual sumária." De fato, a regulamentação do retorno da justiça militar aos julgamentos de condutas vinculadas à conjuntura política veio em abril do ano seguinte, com a edição do Decreto no 21.289 . 
A Constituição de 1934 trouxe uma inovação importante para o funcionamento da justiça militar, pois, segundo seu artigo 63, os juízes e tribunais militares passaram a fazer parte do Poder Judiciário. Esse deslocamento promoveu, também, a extinção da competência administrativa do STM, rompendo em definitivo com a lógica do Império. A nova Constituição previu uma seção especial para dispor sobre a justiça militar de modo mais detalhado do que a anterior. Em seu art. 84, estava disposto que militares e pessoas a eles assemelhadas teriam "foro especial" no julgamento dos delitos militares. Estava prevista, também, a possibilidade de extensão desse foro a civis, com vistas à repressão de crimes contra a segurança externa do país ou contra as instituições militares. As Constituições de 1937 e 1946 manteriam o texto da anterior.

Criado em 1936, como decorrência direta do Levante Comunista de 1935, o Tribunal de Segurança Nacional (TSN) foi inicialmente vinculado à justiça militar, como órgão de primeira instância, sendo que de suas decisões caberia recurso ao STM. Essa determinação promovia, ainda que por curto tempo, o retorno do envolvimento do foro militar com questões políticas. Apesar de ter sido apensado à estrutura da justiça militar, o TSN era claramente um tribunal de exceção, com práticas judiciais como o julgamento por convicção, permitido aos juízes que 0 integravam. ${ }^{26}$ Entre as funções do novo tribunal estavam previstos o julgamento de civis e militares acusados de cometerem crimes contra as instituições militares e contra a segurança externa da República.

O contorno político das ações que caracterizariam tais delitos fez com que os crimes militares continuassem sendo apreciados pelo STM, promovendo a distinção fundamental de foro no início do processo. Como argumenta D'Araujo, o investimento governamental em criar o novo tribunal relacionava-se com o interesse em punir e expurgar do Exército os envolvidos com o Levante de 1935, em meio a um "processo de nacionalização e modernização das Forças Armadas" (2010: 215-216). A vinculação do TSN com a justiça militar durou pouco. Com o golpe de 1937 e o início do Estado Novo, as atribuições e a atuação do TSN foram modificadas, demarcando mais claramente seu caráter de tribunal de exceção, que foi oficialmente desligado do foro militar, passando a funcionar como uma estrutura única e independente. ${ }^{27}$

A fim de sistematizar as modificações introduzidas na justiça militar desde a década de 1920, foi publicado em 1938 o Código de Justiça Militar. ${ }^{28}$ A estrutura da justiça militar era formada, em cada região militar, pelos Conselhos de Justiça e auditores e pelo STM, com alcance a todo o país. Os Conselhos, por sua vez, eram divididos em três categorias que diferenciavam suas funções e alcance: Conselho Especial de Justiça, para julgar oficiais, à exceção dos generais; Conselho Permanente de Justiça, para julgamento de soldados; e Conselho de 
Justiça, no âmbito dos corpos e estabelecimentos do Exército, a fim de processar e julgar desertores e insubmissos. Essa organização refletia duas questões importantes, que perpassam a história da justiça militar. A primeira delas era a manutenção da lógica hierárquica da caserna na estrutura da justiça militar, e a segunda, a necessidade de organizar mecanismos mais eficientes para lidar com o crime de deserção, crime militar por excelência.

Com a promulgação de nova carta constitucional em 1946, a competência da justiça militar continuaria restrita ao julgamento de crimes militares, mantendo sua extensão aos civis, assim como na Carta de 1934. A nova Constituição mudou o nome do Supremo Tribunal Militar para Superior Tribunal Militar (STM).

Com o golpe de 1964, a justiça militar foi envolvida com o movimento persecutório colocado em prática após a deposição do presidente constitucionalmente eleito, João Goulart. Nesse período, o funcionamento do foro militar era determinado pela Constituição de 1946, pelo Código da Justiça Militar de 1938, além de alguns artigos previstos na Lei de Segurança Nacional de $1953,{ }^{29}$ que estabelecia que alguns crimes caracterizados como atentados à segurança externa do país deveriam ser julgados pela justiça militar.

Em 6 de abril de 1964, os ministros do STM aprovaram, por unanimidade, uma moção de apoio e solidariedade ao movimento de 31 de março, enviada ao presidente em exercício, Ranieri Mazzili, presidente do Congresso Nacional. Essa nota daria o tom do engajamento do foro militar no processo político autoritário a partir de então. Os conflitos de competência entre as justiças comum e militar, no que concernia ao julgamento de civis e militares acusados de crimes de natureza política, levaram à edição do Ato Institucional no 2 (Al-2) em outubro de 1965, configurando uma das etapas do processo de institucionalização do regime ditatorial. ${ }^{30} \mathrm{O}$ ato discricionário conferiu à justiça militar a responsabilidade de processar e julgar os crimes previstos na Lei de Segurança Nacional em vigor, além de ampliar o número de ministros do STM de 11 para 15, sendo cinco civis, quatro do Exército, três da Marinha e três da Aeronáutica. A Constituição de 1967 trouxe importante mudança no tocante às atribuições do foro militar. Além do julgamento dos crimes militares, dos militares e das pessoas a eles assemelhadas, a Carta incorporou o conteúdo do Al-2 e determinou que a justiça militar poderia ser estendida aos civis que cometessem crimes contra a segurança nacional ou as instituições militares. Essa mudança promoveu um deslocamento da punição de crimes contra a segurança externa para a segurança interna, delineando a figura do inimigo interno.

Durante a ditadura militar, a justiça militar teve marcadamente uma atuação de Justiça do Regime (Silva, 2011), com nítidas características políticas. Se desde o início do período republicano a responsabilidade da justiça militar oscilava, com determinações pouco 
claras acerca do seu viés político, desde o início do regime ditatorial houve a incontestável opção por sua instrumentalização para apreciação de supostos crimes relacionados à contestação da ordem. Ao longo do período autoritário, a justiça militar foi acumulando funções variadas de apreciação de crimes militares, crimes contra a segurança nacional, crimes contra a probidade administrativa e crimes contra a economia popular, cometidos por civis ou por militares. 0 acúmulo de tais funções relacionava-se com o fato de ser um regime ditatorial implementado pelas Forças Armadas, ainda que com ampla colaboração civil, mas também com a vocação histórica de envolvimento do foro militar com questões de natureza política.

Nesse período, os trabalhos da justiça militar foram pautados por sucessivas leis de segurança nacional editadas em 1967, 1969, 1978 e 1983. Além disso, sua atuação deveria ser regida pelos novos Código Penal Militar, de Processo Penal Militar e de Organização Judiciária Militar, todos editados em 1969 por meio de decretos-lei, durante o curto período de governo de uma Junta Militar. ${ }^{31}$ Nesse amplo conjunto legislativo, cujo conteúdo estava diretamente relacionado ao maior ou menor grau de recrudescimento político, encontrava-se um amplo manancial de crimes e de penas que poderiam ser aplicadas pelos integrantes do foro militar, entre elas a pena de morte, de prisão perpétua e de banimento. Ao exercício de ampla prerrogativa judicial, que era colocada em prática em consonância com o trabalho dos órgãos repressivos, Anthony Pereira chamou de "legalidade autoritária", cujo sentido expressava a existência de, "por um lado, uma esfera de terror extrajudicial e, por outro, uma esfera de legalidade rotineira e bem estabelecida" (2010: 53). ${ }^{32}$

Com o processo de redemocratização e a promulgação da Constituição de 1988, conhecida como "Constituição cidadã", a justiça militar foi mantida com a mesma estrutura de funcionamento do período da ditadura militar. 0 artigo 124 da Carta define que a função do foro militar é julgar "os crimes militares definidos em lei", dando margem à possibilidade de julgamento de civis que cometessem crimes militares. De fato, mais recentemente, tem-se observado o aumento da quantidade de civis julgados por crimes militares, no foro militar. Os casos que mais se destacam estão relacionados à ampliação das funções das Forças Armadas, em ações de "garantia da lei e da ordem", como previsto na Constituição e melhor definido a partir do fim da década de 1990. A determinação de "atribuições subsidiárias militares" 33 forneceu o arcabouço jurídico que permitiu, por exemplo, a ocupação dos Complexos do Alemão, Penha e Maré pelas Forças Armadas, desde 2010. A atuação dos militares nessa região gerou a formação de uma série de processos judiciais contra civis acusados de crimes militares, como desacato e desobediência, cujo destino acabou sendo a justiça militar. ${ }^{34}$ 


\section{CONSIDERAÇÕES FINAIS}

1 justiça militar brasileira constituiu-se como um foro híbrido, caracterizado pelo enconestava associada a uma tradição aristocrática, a composição do corpo de oficiais e o recrutamento eram permeáveis aos valores e hierarquias da sociedade, o que afetava o processo de formalização da justiça militar. A definição de um foro militar, e sua regulamentação por meio de um código, transformaria essa tradição, limitando a liberdade de interpretação das leis, o amplo poder jurisdicional dos oficiais sobre as tropas e 0 arbítrio na aplicação de castigos físicos. Não à toa, o primeiro código penal militar brasileiro - um código da Armada, estendido em seguida ao Exército - só foi publicado em 1890, já no período republicano. Outra marca desse fazer jurídico de base aristocrática era o espelhamento de uma visão de mundo hierarquizada na organização do foro militar. A opção por iniciar a formalização da aplicação dessa justiça por baixo - pelas tropas e baixa oficialidade - evidenciava o desejo de preservar uma ordem social desigual, fundada na escravidão. A tardia criação e regulamentação de instâncias da justiça militar destinadas à alta oficialidade assegurava privilégios e distinções, que seriam mantidas ao longo da República.

As intervenções militares em questões da política nacional resultaram em um total transbordamento das fronteiras da justiça militar para a inclusão de apreciações de natureza política. A busca pela modernização e profissionalização militar, na primeira metade do século $X X$, não eliminou o envolvimento das Forças Armadas com os temas da política nacional (Carvalho, 2006; McCann, 2007). Esse movimento resultou na oscilação da justiça militar acerca do julgamento de condutas consideradas desordeiras, subversivas ou atentatórias à segurança nacional. Tal característica acabou por manter a possibilidade de julgamento de civis pelo foro militar, prerrogativa existente até hoje. Ressalta-se que o Brasil é um dos poucos países democráticos da América Latina a manter um foro militar, com características corporativas, acrescidas da possibilidade de julgar civis (Rial, 2010: 64). Tal disposição pode ser compreendida como um reflexo da tradição de pertencimento distinto e aristocrático que ainda caracteriza a instituição militar.

0 passeio pela legislação que regula a existência da justiça militar não é suficiente para a compreensão do impacto da junção entre o campo militar e o jurídico, assim como das implicações que esse predicado trouxe para a complexa atuação do foro militar. Faz-se necessário, então, o desenvolvimento de pesquisas que investiguem o cotidiano judicial da justiça militar ao longo da sua história, e que permitam aprofundar o entendimento sobre sua atuação para além dos seus contornos definidos em lei. 


\section{NOTAS}

1 Ver Acórdão de HC no 113.128 - RJ. Arquivo do STF. Disponível em: http://bit.ly/1XepLe7. Acesso em: 21/04/2016.

2 Entre 2005 e 2007, o CPDOC/FGV coordenou pesquisa sobre a história da Justiça Militar brasileira, por ocasião dos 200 anos do foro. Contudo, a pesquisa não chegou a ser publicada. Boas fontes de pesquisa são os livros de João Vieira de Araújo, Esmeraldino Bandeira e Chrysólito de Gusmão, especialistas da área de direito, com livros publicados no início do século XX.

3 Fundo Vice Reinado, cód. D9, caixa: 483, pacote 2, doc. 4. Arquivo Nacional (AN).

4 Idem. Doc. 35. AN.

5 Essa crítica pode ser encontrada em artigos e livros publicados entre finais do século XVIII e início do XIX, Bibliothèque Nacionale de France - BNF.

6 Uma memória chave é a do marquês de Alorna. Arquivo Nacional da Torre do Tombo/ANTT - Casa Fronteira e Alorna - Família Oyenhousen. Há, ainda, o Livro de Actas das sessões da Junta do Código Penal Militar. Arquivo Histórico Militar de Lisboa, 4a Divisão - 4/1/10/23.

7 Fundo Vice Reinado, cód. D9, caixa: 483, pacote 3, doc. 45. AN.

8 Um resumo cronológico de toda a legislação sobre os Conselhos de Guerra encontra-se em Sampaio (1824) e Amaral (1863). Ver: http://iuslusitaniae.fcsh.unl.pt/.

90 alvará está disponível em: http://bit.ly/1XepLe7.

10 Para a criação do Conselho do Almirantado, ver alvará de 25/04/1795. Disponível em: http://iuslusitaniae. fcsh.unl.pt/. Para o Conselho Naval, ver a lei de 23/08/1856 e o decreto de 22/07/1858. Disponível em: http:// bit.ly/1YgGrCc. Acesso em 15/04/2016.

11 Livro de Actas das sessões..., op.cit.

12 Sobre princípios e práticas penais de Antigo Regime, ver Hespanha (1993) e Lara (1999).

13 Devido à ausência de pesquisas sobre a história da Justiça Militar, sua atuação ainda é desconhecida. Soma-se a isso a dificuldade de localizar os processos que tramitaram no foro ao longo do século XIX.

14 Ver $\S 30$ do art. 2으 da lei.

15 Ver Decreto ํo 1.631 de 18/08/1855.

16 No documento de trabalho sobre os 200 anos da justiça militar (CPDOC/FGV), Lemos já apontava para essa dificuldade de sistematização. Ver também Lemos (2012).

17 Coleção de Leis do Império do Brasil, 1889, p. 316. Disponível em: http://bit.ly/1TvaPm7. Acesso em: 21/04/2016. 0 decreto foi revogado quase um ano depois, por meio do Decreto 1.069, de 22/11/1890.

180 termo "militarmente" está presente no art. 1ํ do decreto.

19 Entre os assuntos presentes nos pedidos de mudanças no funcionamento das forças militares estavam a abolição dos castigos corporais, definições acerca do serviço militar obrigatório e alterações nas regras disciplinares. 
20 Ver Decreto no 949, de 05/11/1890. Disponível em: http://bit.ly/1TvaPm7. Acesso em: 21/04/2016.

21 Segundo o texto do código, o que chamamos de civil era definido como "todo indivíduo estranho ao serviço da marinha de guerra".

220 Decreto no 18, de 07/03/1891, promoveu mudanças no Código Penal da Armada.

23 Ver Decreto no 14.450, de 30/10/1920 e Decreto oㅜ 14.544, de 16/12/1920.

24 Observa-se uma continuidade no uso da nomenclatura desde fins do século XVIII, quando foi instituída a função de auditor regimental que, em seguida, deixou de estar vinculada a um regimento militar. Nas primeiras décadas republicanas, há uma reconfiguração das instâncias internas do foro militar, mantendo a figura do auditor como o elemento do mundo civil e jurídico na primeira instância.

25 Ver Decreto № 20.656, de 14/11/1931.

26 Ver Lei no 244, de 11/09/1936.

27 Ver o Decreto-Lei (DEL) ํo 88, de 20/12/1937. Para maiores informações sobre a atuação do TSN, ver D'Araujo (2010).

28 Ver Decreto-Lei no 925, de 02/12/1938. No mesmo ano, já haviam sido editados dois decretos-lei importantes, definindo os crimes contra a personalidade internacional, a estrutura e segurança do Estado e contra a ordem social (DEL № 431, de 18/05) e dispondo sobre o processo e julgamento dos civis em foro militar (DEL № 510, de 22/06).

29 Ver Lei no 1.802, de 05/01/1953.

30 Ver Alves (1985), Klein e Figueiredo (1978), Martins Filho (1996) e Silva (2011). Para Lemos, durante a ditadura, a Justiça Militar atuou como "órgão central do aparato de coerção jurídica" e "como instrumento auxiliar na estratégia de legitimação do regime" (2004: 424).

31 Para conferir o conteúdo deste conjunto de dispositivos legislativos, ver: Constituição de 1967; DEL № 314, de 13/03/1967; DEL o 898, de 29/09/1969; Emenda Constitucional no 1, de 17/10/1969; DEL no 1.001, 1.002 e 1.003, de 21/10/1969; DEL no 1.632, de 04/08/1978, que estende os efeitos da Lei de Segurança Nacional para a legislação trabalhista; Lei no 6.620, de 17/12/1978 e 7.170, de 14/12/1983.

32 No Relatório Final da Comissão Estadual da Verdade do Rio de Janeiro, Vanessa Berner propõe a ideia de "ilegalidade autoritária" para se referir à atuação do Poder Judiciário e ao não cumprimento das leis por parte de seus integrantes. Ver pesquisa "Justiça autoritária? Uma investigação sobre a estrutura da repressão no Poder Judiciário do Estado do Rio de Janeiro (1964-1985)", disponível em: http://www.cev-rio.org.br/ relatorios/pesquisas-faperj. Acesso em 25/04/2016.

33 Ver Lei Complementar (LCP) o 97, de 09/06/1999; LCP no 117, de 02/09/2004; LCP no 136, de 25/08/2010.

34 Ver levantamento feito por Juliana Dal Piva em 'Tribunais de Repressão': processos contra civis dispararam com as UPPs. Disponível em: http://bit.ly/1ZBYCAO. Acesso em: 21/04/2016.

\section{REFERÊNCIAS BIBLIOGRÁFICAS}

ABREU, L. Pina Manique: um reformador no Portugal das luzes. Lisboa, Gradiva, 2013. 
ALMEIDA, A. L. da C. Repertório remissivo da legislação da Marinha e Ultramar compreendida de 1317 até 1856. Lisboa, Imprensa Nacional, 1856.

ARQUIDIOCESE de São Paulo. Brasil: nunca mais. 2a ed. Petrópolis: Vozes, 1985.

BERBOUCHE, A. Marine et justice. La justice criminelle de la Marine française sous l'Ancien Régime. Rennes: Presses Universitaires de Rennes, 2010.

CARVALHO, J. M. de. Forças Armadas e política no Brasil. 2ª ed. Rio de Janeiro: Zahar, 2006.

COITINHO, A. do C. Sob a toga e a farda: o ministro general de Exército Rodrigo Octávio Jordão Ramos no Superior Tribunal Militar (1973-1979). Mestrado em História, Unirio, 2012.

D'ARAUJO, M. C. S. de. Militares, democracia e desenvolvimento: Brasil e América do Sul. Rio de Janeiro: FGV, 2010.

FAGUNDES, J. B. da S. 0 crime político na Justiça Militar. Revista do STM, Brasília, jul. 1977 a jun. 1978, p. 83-103.

GUINIER, A. L'honneur du soldat. Éthique martiale et discipline guerrière dans la France des Lumières. Rhône: ChampVallon, 2014.

HESPANHA, A. M. de. Justiça e litigiosidade. História e prospectiva. Lisboa: Calouste Gulbenkian, 1993.

LARA, S. H. Introdução. In: Ordenações Filipinas. Livro V. São Paulo: Companhia das Letras, 1999.

LEMOS, R. Justiça fardada: o general Peri Bevilacqua no Superior Tribunal Militar (1965-1969). Rio de Janeiro: Bom Texto, 2004.

Poder Judiciário e poder militar (1964-69). In: CASTRO, C. et al. (org.). Nova história militar. Rio de Janeiro: FGV, 2004, p. 409-438.

A Justiça Militar e a implantação da ordem republicana no Brasil (1889-1895). Topoi, Rio de Janeiro, v. 13, p. 60-72, 2012.

MACIEL, W. A. Repressão judicial no Brasil: o capitão Carlos Lamarca e a VPR na Justiça militar (1969-1971). Mestrado em História, USP, São Paulo, 2003.

MATTOS, M. A. V. L. de. Em nome da segurança nacional: os processos da Justiça militar contra a Ação Libertadora Nacional (ALN), 1969-1979. Mestrado em História, USP, São Paulo, 2002.

McCANN, F. Soldados da pátria: história do Exército brasileiro (1889-1937). São Paulo: Companhia das Letras, 2007.

PEREIRA, A. Ditadura e repressão: o autoritarismo e o Estado de direito no Brasil, no Chile e na Argentina. São Paulo: Paz e Terra, 2010.

RIAL, J. La justicia militar: entre la reforma y la permanencia. Buenos Aires: RESDAL, 2010.

SAMPAIO, A. M. da S. Instruções para o uso dos oficiais do Exército Nacional e Imperial nos processos de conselho de guerra. Rio de Janeiro: Typographia Nacional, 1824.

SAMPAIO, C. A. H. de O. Justiça Militar brasileira, Revista do Superior Tribunal Militar, Brasília, 1976, s/n, p. 65-81. 
SILVA, A. M. D. da. Ditadura e Justiça militar no Brasil: a atuação do Superior Tribunal Militar (1964-1980). Doutorado em História, PPHPBC, FGV, 2011. Justiça e ditadura militar no Brasil: o julgamento dos crimes contra a economia popular. Diálogos, Maringá, v. 18, p. 51-73, 2014.

. Justiça e autoritarismo no Brasil: crime contra a segurança nacional e pena de morte durante a ditadura militar. Dimensões: Revista de História da UFES, v. 32, p. 111-127, 2014.

SOUZA, A. B. de. Um edifício gótico entre instituições modernas: o debate parlamentar sobre o Conselho Supremo Militar e de Justiça (1822-1860). Acervo, v. 25, p. 59-77, 2012.

. Duque de Caxias: o homem por trás do monumento. Rio de Janeiro, Civilização Brasileira, 2008.

. O Exército na consolidação do Império: um estudo sobre a política militar conservadora. Rio de Janeiro: Arquivo Nacional, 1999.

. A governança da justiça militar entre Lisboa e Rio de Janeiro (1750-1820). Almanack, v. 5, p. 368-408, 2015.

SUBTIL, J. Um caso de estado vésperas do regime liberal: Portugal século XVIII. In: MOITA, L. Do Império ao Estado: morfologias do sistema internacional. Lisboa, Observare-Ediual, 2013. 